\title{
Determinants of Group Loan Repayment Performance of Micro and Small Scale Enterprises: Case Study Oromia Credit and Saving Share Company (EasternWollega Zone Branch)
}

\author{
Mr. AmanuDabaWaktola (MSc.) \\ Wollega University, Department of Economics, Nekemte, Ethiopia
}

\begin{abstract}
The study was intended to analyze the determinants of group loan repayment performance of MSE's sectors a case of Oromia Credit and Saving Share Company operating in the East Wollega Zone. The survey data was conducted by using the structured questionnaire in order to collect primary data from the purposively selected branches whereas secondary data were collected from published and unpublished documents. Out of 424 total number of groups owned of MSE's sectors 168 sample size were selected and only 162 of the respondents have filled the questionnaire properly by their respective enterprise's group leaders. The collected data were analyzed by employing descriptive statistics and ordered logit model by using STATA soft ware version 12. Result of this study shows that out of the predicting variables used in this study, group leaders education level, group leaders experience in similar business, the enterprise's beginning capital, loan repayment period, loan follow up, Training offered by the loan officers of OCSSCO and access to output market for the enterprises finished products were found to positively influence while the enterprises group size, additional loan they received, problem of information disclosure among members, the problem of financial statement recording experience in the business, loan interest rate, problem of power interruption and shortage of water supply around the enterprise working area have negatively influenced the group loan repayment performance of MSE's sectors in the study area. Based on this result, the author recommended that OCSSCO has to focus on the smaller the group size through which the problem of information disclosure would be resolved, they has to give frequent training about the financial statement recording experience, they have to deal with the concerned body to solve the problem of power interruption as well as about the shortage of water supply around the enterprise's business area and encouraging them to increase their beginning capital at the enterprise start up that used to build confidence in their loan repayment performance in thestudy area.
\end{abstract}

Keywords: Loan repayment performance, Micro and Small Scale Enterprises, Oromia Credit and Saving Share Company.

DOI: $10.7176 / \mathrm{JESD} / 11-19-04$

Publication date:June 30th 2020

\section{Introduction}

Ethiopia's micro financing institutions (MFIs) are emerged with unique opportunity to serve poor people who do not have access to provision of micro-credit, savings, and other services to the poor that are excluded by the banks for collateral and other reasons. Microfinance is relatively new to Ethiopia and came to existence during 1994-95 with the government's licensing and supervision of microfinance institution proclamation No 40/1996, and the main objective of these institutions are to deliver micro-loans, micro-savings, micro-insurance, money transfer, leasing, etc to a large number of productive resource up to poor people in the country in a cost-effective and sustainable way (Zerai and Rani, 2012).

Since, the primary objectives of Ethiopia's MFIs are to offer financial services such as credit and saving to the poor in order to mitigate financial constraints of the public in the country, Accordingly, Microfinance institutions supply loans mostly to urban and rural peoples who cannot afford collaterals to get loans from banks. Microfinance institutions provide credit to the poor who lack access of formal credit from financial institutions. Though those micro-finance sectors offer credit to the poor, currently they faced a problem of loan repayment delay (defaulters) by clients. Since, Oromia Credit and saving Share Company is one of the micro finance institutions among those operating in the country particularly that is found in Oromia regional state which is also facing a similar problem of defaulters (Facet, 2013).

In this regard, the data overview from OCSSCO of East Wollega Zone by focusing on the loan disbursed, loan paid back and the amount defaulted and the defaulted rate of last five years is summarized as follows: 
Table.1.1.Group loan repayment performance of MSE's Sectors for the successive past five (5) years financed by OCSSCO of East Wollega Zone

\begin{tabular}{|lccccc|}
\multicolumn{1}{c}{ Years } & $\mathbf{2 0 1 1 / 1 2}$ & $\mathbf{2 0 1 2 / 1 3}$ & $\mathbf{2 0 1 3 / 1 4}$ & $\mathbf{2 0 1 4} / 15$ & $\mathbf{2 0 1 6 / 1 7}$ \\
\hline Amount disbursed & $15,563,899.00$ & $16,183,034.00$ & $27,286,399.00$ & $25,675,950.00$ & $22,588,656.00$ \\
\hline Amount collected & $14,904,658.00$ & $14,109,004.00$ & $21,675,865.00$ & $22,966,417.00$ & $18,241,144.00$ \\
\hline Amount defaulted & $659,241.00$ & $2,074,030.00$ & $5,610,534.00$ & $2,709,533.00$ & $4,347,512.00$ \\
\hline Default rate & $\mathbf{7 \%}$ & $\mathbf{1 2 . 8 \%}$ & $\mathbf{2 0 . 5 \%}$ & $\mathbf{1 0 . 5 \%}$ & $\mathbf{1 9 . 2 \%}$ \\
\hline
\end{tabular}

Source: East Wollega Zone OCSSCO Office (2017)

As discussed in the table 1.1 above, the default rate of the MSE's group borrowers of different sectors for the last five years was reached about $14 \%$ at average which is greater than the National Bank of Ethiopia's (NBE) minimum requirement set for all financial institutions, i.e., $<5$ percent default rate or $>95$ percent expected to be collected. Separately, the default rate was $7 \%, 12.8 \%, 20.5 \%, 10.5 \%$ and $19.2 \%$ in the successive five years from $2011 / 12$ - 2016/17 respectively and the trend of default rate increasing for the three successive years from $7 \%$ to $12.8 \%$ then to $20 \%$ in the years $2011 / 12-2013 / 14$ and $10.5 \%$ in $2015 / 16$. Though the default rate was decreased to $10.5 \%$ in the year of $2015 / 16$, currently it increases to $19.2 \% \%$ in the year $2016 / 17$. Finally, this indicates that the loan repayment performances for the group borrowers of MSE's Sectors have been significantly fluctuating from time to time and become severe in the current year. In such away, whether the defaulting problem is random and influenced by inconsistent behavior or it is influenced by certain factors in a specific situation, it needs an empirical investigation in the study area. Hence, these gaps calls for the study in order to fill a stock of knowledge gap in the study area. Thus, the author aims to find out the determinants of group loan repayment performance of MSE's sectors: a case of East Wollega Zone Oromia credit and saving Share Company.

\section{Methodology of the study}

\subsection{Data type and sources}

Since data sources are the most important points to address the main objective of the study. Thus, this study was employed both primary and secondary data types for its credibility in which primary data was collected through structured and interview based questionnaire containing both close and few open ended one from MSE's group leaders because they are the one who expected to know the required information of the members in the group. While the secondary data sources were collected from published and unpublished documents at OCSSCO of East Wollega zone office, concerning determinants of the group loan repayment performance of MSE's sector levels in the study area.

\subsection{Sampling design}

The targeted populations in this study were categorized in to three strata's such as; Non-defaulter, Risky and Defaulter groups with their respective MSE's Sectors i.e. Manufacturing, Construction, Agriculture, Service and Trade sectors a case of East Wollega Zone of Oromia Credit and Saving Share Company operating branches. As a result, from twenty branches operating in the study area eleven of them werepurposively selected based on the branches having three strata's of MSE's loan repayment status. Thus, purposive sampling design was applied to this study in order to select the group leader respondents of MSE's sectors so as to keep the population proportion of the respondents determined weights. This is because group leader is the one who looks after their members and supervises them so that they know the required information concerning the members in the study area.

\subsection{Sample size Determination}

This study was conducted in the case of Oromia credit and saving share company in East Wollega Zone of Oromia regional states locating at the western direction of the country having twenty operating branches under it. Hence, this study was mainly focusing on the group leaders of MSE's different sectors that are financed by each branches of OCSSCO in the study area. The total populations included in the study were selected based on the classification and structure made by NBE that is given to micro finance institutions as a report format to be reported accordingly concerning the group loan repayment status of MSE's borrowers of different sectors in which they are classified into three groups as: good group borrowers (non-defaulter groups)who repaid the loan on time, risky group borrowers who couldn't pay the loan for one year (365 days) from the past due date those who are warned more than three times and defaulter group borrowers who couldn't pay the loan in full for more than one year $(>365$ days) from the past due date.

Hence, this study was tried to choose those targeted populations based on the purpose of data analysis and methodology to be employed as observed from the surveyed data showing the group loan repayment status of MSE's in sectored bases which was used to determine the sample size needed for the study from the targeted total population in the study area. The target populations which was incorporated in the study were grouped in to three strata's as; non-defaulter groups risky groups and defaulter groups with respect to MSE's Sectors i.e. 
manufacturing, construction, agriculture, service and trade sectors. Therefore, the sample size for each of the five MSE's sectors was determined by allocating their respective number in which they are categorized. According to J.Watson's, (2001) the initial sample size $(n)$ proportionally to each strata's and with respect to all sectors were calculated by using his sample size formula shown in the table 3.1 below.

Table 2.1.Loan Repayment Performance of MSE's Sectors with their Level of Default Status

\begin{tabular}{|c|c|c|c|c|}
\hline \multicolumn{4}{|c|}{ Group owned of MSEs loan repayment status } & \multirow[b]{2}{*}{ Grand Total } \\
\hline Types of sectors & Non defaulter groups & Risky groups & Defaulter groups & \\
\hline Manufacturing & 25 & 32 & 23 & 80 \\
\hline Construction & 27 & 38 & 22 & 87 \\
\hline Agriculture & 26 & 34 & 30 & 90 \\
\hline Service & 22 & 28 & 35 & 85 \\
\hline Trade & 24 & 30 & 28 & 82 \\
\hline Total populations (N) & 124 & 162 & 138 & 424 \\
\hline Weight $=\frac{N * 168}{424}$ & 49 & 64 & 55 & 168 \\
\hline
\end{tabular}

Source: East Wollega Zone OCSSCO Office, (2017).

Thus, the sample size was determined by using the J.Watson's, (2001) standardized statistical formula is calculated as:

$$
\begin{aligned}
& n=\frac{\frac{p[1-p]}{A^{2}+\frac{p[1-p]}{N}}}{R} \text { Where, } \\
& \mathrm{n}=\text { sample size required } \\
& \mathrm{N}=\text { a number of the total population included in the study (424) } \\
& \mathrm{P}=\text { estimated variance in population, as a decimal: }(0.2) . \\
& \mathrm{A}=\text { Precision desired, expressed as a decimal (i.e., } 0.05, \text { for } 5 \%) \\
& \mathrm{Z}=1.96 \text { for } 95 \% \text { confidence level. } \\
& \mathrm{R}=\text { Estimated Response rate, as a decimal i.e. } 95 \%(0.95) . \\
& \quad n=\frac{\frac{0.2[1-0.2]}{1.96^{2}}+\frac{0.2[1-0.2]}{424}}{0.95}
\end{aligned}
$$

$n=168$

According to J.Watson's, (2001) the proportional sample size $(n)$ with respect to the total populationis calculated as $n=\frac{124 * 168}{424}=49$, similarly, a sample of 64 , and 55 , are selected to be respondents of the study from the three strata's with respect to each sectors respectively.

As a result, the determined proportionate sample size from the total population (424) is $\mathbf{4 0 \%}$ representative of the total targeted populations in the study area. Though, a total of one hundred sixty eight (168) respondents were selected as sampled respondents, $\mathbf{1 6 2}$ of them filled out the questionnaire properly that was used for analysis regarding the determinants of group loan repayment performance of micro and small scale enterprise's sectors that are financed by OCSSCO in the study area.

\section{Result and Discussions}

This part presents the results from the descriptive and econometric analysis. The descriptive analysis made by using statistical tools such as, tables, percentage, mean and frequency distribution. Whereas the econometric analysis were employed ordered logit model in order to examine the group loan repayment performance of MSE's sectors that are financed by East Wollega Zone of Oromia Credit and Saving Share Company to identify what factors influence them either to fall in non-defaulters risky or defaulter groups with respect to some explanatory variables included in the study.

Table 3.1.Genderof the sampled respondents

\begin{tabular}{|c|c|c|}
\hline Gender of group leader respondents & Freq. & Percent \\
\hline Female & 65 & 40.12 \\
\hline Male & 97 & 59.88 \\
\hline Total & $\mathbf{1 6 2}$ & $\mathbf{1 0 0 . 0 0}$ \\
\hline
\end{tabular}

\section{Source: Computation result from field survey, 2017.}

Out of 424 total targeted population of the study area, 168 sample respondents were selected for this study by using sample size determination formula which was discussed earlier in the methodology part. Accordingly from the selected number of respondents only 162 of them filled out the questionnaire properly while the rest of 6 
questionnaires couldn't be collected from the respondents due to their lack of interest to fill it in the study area. As depicted in the table 4.1 above, from 162 sample respondents; male respondents were acquired a larger share accounting $59.88 \%$ and followed by females accounted $40.12 \%$.

Figure 3.1.Age of the sampled respondents

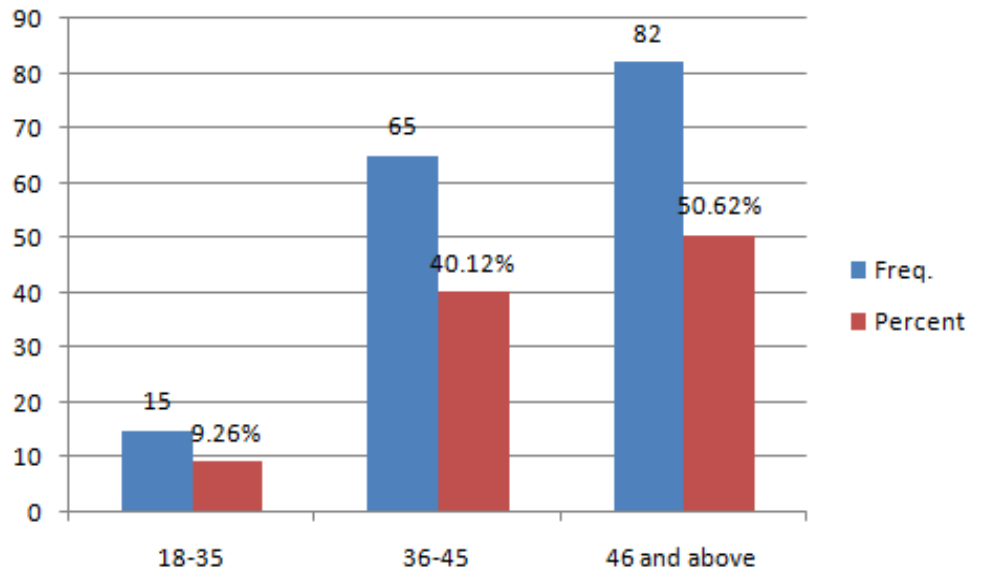

Source: Computation result from field survey, 2017

As presented in the figure 3.1 above, among the sampled respondents of the group leader from the various Sectors in the enterprises; $50.62 \%$ of them belong to the age category of 46 and above years old and followed by the age between $36-45$ then $18-35$ year's accounting $40.12 \%$ and $9.26 \%$ respectively in the study area.

Figure 3.2.Marital Status of the sampled respondents

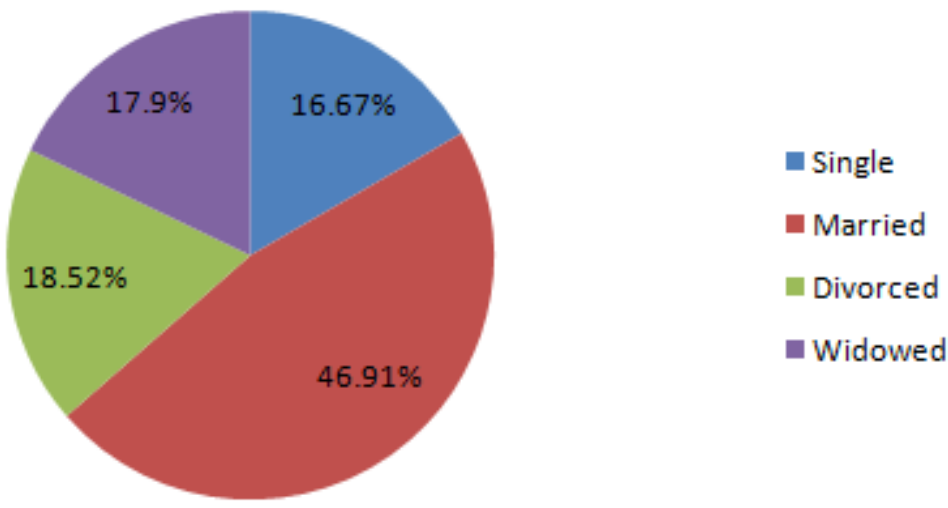

Source: Computation result from field survey, 2017

From figure 3.2 above it is depicted that the highest percentage share of the marital status by the sampled respondents were married individuals followed by divorced, widowed and the single accounting $46.91 \%, 18.52 \%$, $17.9 \%$ and $16.76 \%$ respondents respectively .

Table 3.2.Comparative analysis among MSE sectors and their loan repayment status

\begin{tabular}{|lcccccc|}
\hline MSE's loan & \multicolumn{2}{c}{ Sectors of the micro and small scale enterprises } \\
repayment status & Construction & Service & Manufacturing & Agriculture & Trade & Total \\
\hline Non defaulter & 10 & 10 & 10 & 8 & 11 & $\mathbf{4 9}$ \\
\hline Risky & 13 & 7 & 16 & 10 & 12 & $\mathbf{5 8}$ \\
\hline Defaulter groups & 15 & 9 & 8 & 7 & 16 & $\mathbf{5 5}$ \\
\hline Total & $\mathbf{3 8}$ & $\mathbf{2 6}$ & $\mathbf{3 4}$ & $\mathbf{2 5}$ & $\mathbf{3 9}$ & $\mathbf{1 6 2}$ \\
\hline
\end{tabular}

Source: Computation result from field survey, 2017

As depicted in the table 3.2 above, the comparative analysis among the types of sectors that MSE engaged in reveals that the loan repayment performance across the three successive sectors such as; construction, service and manufacturing sectors were similar being non defaulter while the agricultural sector performs less than all sectors and the only trade sector performs well when compared to others. 
Table 3.3.Summary for the Descriptions of the Variables

\begin{tabular}{|c|c|c|}
\hline Variables & Descriptions & Value of labels \\
\hline $\begin{array}{l}\text { Dependent } \\
\text { Variable }\end{array}$ & $\begin{array}{l}\text { Group loan repayment status or performance } \\
\text { of MSE various sectors }\end{array}$ & 0= Non defaulter, $1=$ Risky, $2=$ Defaulter \\
\hline $\begin{array}{l}\text { Independent } \\
\text { variables }\end{array}$ & \multicolumn{2}{|l|}{ Demographic characteristic of respondents } \\
\hline GNDR & Gender of the respondents. & $0=$ Female, $1=$ Male \\
\hline AGE & Age of the respondents. & Measured in years \\
\hline MRSTS & Marital status of respondents. & $0=$ Single, $1=$ Married, $2=$ Divorced, $3=$ Widowed \\
\hline GLEL & MSE's group leader respondent's education level. & $\begin{array}{l}0=\text { Below primary school, } 1=\text { just Primary school } \\
2=\text { Secondary school,3=Preparatory school } \\
4=\text { TVET school,5= Degree and above }\end{array}$ \\
\hline MSESE & $\begin{array}{l}\text { The sectors that MSE's group leader respondents engaged } \\
\text { in. }\end{array}$ & $\begin{array}{l}0=\text { For Construction }, 1=\text { For Service } \\
2=\text { For Manufacturing }, 3=\text { For Agriculture } \\
4=\text { For Trade }\end{array}$ \\
\hline \multicolumn{3}{|c|}{ The MSE's group or enterprise related factors } \\
\hline GLEX & $\begin{array}{l}\text { An experience in which group leader have } \\
\text { in similar business. }\end{array}$ & $0=$ If not experienced, $1=$ If experienced \\
\hline EGS & Group size in the enterprise & Measured in numbers \\
\hline GSS & Are your group members self selected? & $0=$ If not self selected, $1=$ If self selected \\
\hline ADNL & $\begin{array}{l}\text { The additional loan received by the MSE from OCSSCO to } \\
\text { run their business. }\end{array}$ & $0=$ If not received, $1=$ If received \\
\hline LWNG & $\begin{array}{l}\text { The letter of warning written for a failure to meet the loan } \\
\text { repayment schedule. }\end{array}$ & $0=$ If not written, $1=$ If written \\
\hline PIDR & $\begin{array}{l}\text { The Problem of information disclosure on the loan } \\
\text { repayment status of their enterprise among members. }\end{array}$ & $0=$ If not disclosed, $1=$ If disclosed \\
\hline EBC & The enterprises beginning capital & Measured in birr \\
\hline ELS & $\begin{array}{l}\text { The total loan size that the enterprises received from } \\
\text { OCSSCO. }\end{array}$ & Measured in birr \\
\hline EEC & The enterprises ending or current capital. & Measured in birr \\
\hline PFSRE & $\begin{array}{l}\text { The problem of financial statement recording experience in } \\
\text { your enterprise. }\end{array}$ & $0=$ If not experienced, $1=$ If experienced \\
\hline NEMP & The number of individuals employed in the enterprise. & Measured in number \\
\hline \multicolumn{3}{|c|}{ The institutional related factors } \\
\hline EATL & $\begin{array}{l}\text { Easily accessibility of the loan from OCSSCO to the } \\
\text { enterprises. }\end{array}$ & $0=$ If not easy to access, $1=$ If easily accessed \\
\hline IRRO & $\begin{array}{l}\text { Effect of the internal rules and regulations of OCSSCO } \\
\text { influencing the loan repayment performance of the } \\
\text { enterprises. }\end{array}$ & $0=$ If it not influences, $1=$ If it influences \\
\hline FULO & $\begin{array}{l}\text { The existence of proper follow-up from loan officers of } \\
\text { OCSSCO. }\end{array}$ & $0=$ If follow up not exists, $1=$ If it exists \\
\hline TLO & $\begin{array}{l}\text { The training offered by loan officers of OCSSCO to the MSE } \\
\text { sectors. }\end{array}$ & $0=$ If training not offered, $1=$ If it is offered \\
\hline LRPS & Does the loan repayment period is suitable? & $0=$ If not suitable, $1=$ If suitable \\
\hline LIR & The effect of loan interest rate levied by OCSSCO. & $0=$ If interest not affects, $1=$ If it affects \\
\hline \multicolumn{3}{|c|}{ The external related factors } \\
\hline PSH & The problem of shade at the MSE sectors Working area. & $0=$ If problem of shade not exists, $1=$ If it exists \\
\hline PPI & $\begin{array}{l}\text { the problem of power interruption that the } \\
\text { MSE sectors faced at their working area. }\end{array}$ & $0=$ If power interruption not exists, $1=$ If it exists \\
\hline SHWS & $\begin{array}{l}\text { Does your enterprise encounter the shortage of water supply } \\
\text { at your business area? }\end{array}$ & $0=$ If not encountered, $1=$ If encountered \\
\hline ROA & The road accessibility to the enterprise working area. & $0=$ If access to road not exists, $1=$ If it exists \\
\hline LAIM & $\begin{array}{l}\text { The effect of low access to input market to the esterase's } \\
\text { business working area. }\end{array}$ & $\begin{array}{l}0=\text { If not access to input market, } \\
1=\text { If access to input market }\end{array}$ \\
\hline AOMFP & $\begin{array}{l}\text { Accessibility of output market to the enterprise's finished } \\
\text { product. }\end{array}$ & $\begin{array}{l}0=\text { If not access to output market } \\
1=\text { If access to output market }\end{array}$ \\
\hline
\end{tabular}

\subsection{Ordinal logistic regression model}

\subsubsection{The Econometric model tests, results and analysis}

\subsubsection{Model Specification Tests}

Before extracting the factors of the exploratory variables, reliability assessment were conducted by testing various types of tests that the model needs in order to ensure that the variables comprising each factors are highly reliable and internally consistent (Hair et al., 1998, cited in Cheng and Choy, 2007). 


\subsection{Goodness of fit test of the model}

The measure of goodness-of-fit test used in the ordered logit regression model was the pseudo $\mathrm{R}^{2}$ and $\mathrm{p}$ - value of the model output which is a measure that at least lies in the $[\mathbf{0}, \mathbf{1}]$ interval is normal in ordered logit regression model (Windmeijer, 1995) and (Pindyck\&Rubinfeld, 1998). As shown in table 3.5below the model output showed that the pseudo $\mathrm{R}^{2}$, Chi-square and the $\mathrm{p}$ - value were $\mathbf{0 . 6 2 3 4 , 2 2 1 . 4 1}$ and $\mathbf{0 . 0 0 0 0}$ respectively. This reveals that the ordered logistic regression model was correctly predicted by the predicting variables incorporated in this study. Thus, the probabilities that the group loan repayment performance of MSE's sectors assumed that the proportion of the statistical parametric values where suited with the model and tried to be answered by using STATA software version 12as well as the model result were interpreted below (See Table 3.5)

\subsection{Multicollinearity test.}

In order to understand the reliability of the model were tested before running the model; in this case explanatory variables in the ordered logit model were checked for Multicollinearity (Verbeek, 2008). Since, Multicollinearity is a problem when the explanatory variables in the model are highly correlated and provide redundancy information about the response. The existence of Multicollinearity in the model may cause large variance, large T-value and misleading results (Hosmer, D., \&Lemeshow, S, 1980). Thus, the two popular methods which used to detect the presence of Multicollinearity are Variance Inflation Factor (VIF) and Tolerance (TOL) that calculated as follows;

$$
\mathrm{VIF}_{i}=\frac{1}{1-R_{i}{ }^{2}}, T O L=1-R_{i}^{2}
$$

Where, $\mathrm{R}^{2}$ is calculated by regressing the variables, a common rule of Verbeek indicates that if VIF is 10 or greater than 10 and a TOL of 0.10 or less it may indicate the presence of Multicollinearity problem in the model otherwise free from the problem in the model (See Appendix 1)

\subsection{The link test in the model}

The link test looks for a specific type of the model's specification error by evaluating the following statistical measurements

Table 3.3.The link test in the model

\begin{tabular}{|c|c|c|}
\hline Source & df $\quad$ MS & Number of obs=162 \\
\hline Model & $79.46932 \quad 39.7346$ & $F(2,159)=259.90$ \\
\hline Residual & 24.308159 .1528 & $\begin{array}{l}\text { Prob }>F=0.0000 \\
\text { R-squared }=0.7658 \\
\text { Adj. } R \text {-squared }=0.7628\end{array}$ \\
\hline Total & $103.777 \quad 161.6446$ & Root MSE = 0.391 \\
\hline Loan status & Std. Err & [95\% Conf. \\
\hline hat & 1.137745 .13239198 .59 & 0.000 .8762718 \\
\hline hatsq. & $-.0677259 .0614088-1.10$ & $0.72-.189008$ \\
\hline cons & $-.0368661 .0643032-0.57$ & $0.567-.1638647$ \\
\hline
\end{tabular}

Source: Computation result from field survey, 2017

From this table, it is indicated that, $\mathbf{P r o b}>\mathbf{F}=\mathbf{0 0 0 0}, \mathbf{P}>\mathbf{t}=\mathbf{0 . 0 0 0}$ shows that the model fits well and significant as well as the lower hatsq (0.06) indicates the lower the link error among the dependent and independent variables and it is insignificant which means that there is no miss specified variables in the model.

\subsubsection{Ordered logistic regression model results}

Ordinal logistic regression models the model that was employed in this study because; the outcomes or the response of dependent variable was ordinal having more than two responses (Peterson \& Harrell, 1990). Since, ordered Logistic Regression (OLR), a statistical technique that can be used with an ordered (from low to high) response of the dependent variables and in this study the hypothetical data set has three response of the group loan repayment performance with their ascending order based on the level of severity of their danger which were categorized as non-defaulted groups, risky groups and defaulted groups that are coded as $0=$ for non-defaulted, $1=$ for risky and $2=$ for defaulted groups respectively.

\subsubsection{The summary statistics of the variables in the model}

The summary statistics of the both dependent and independent variables in the model were presented by using the mean, standard deviation, minimum and the maximum values across all individual observations.

In order to interpret this statistically summarized data it is better to see the meet of the data on the group loan repayment performance of the MSE sectors across the three outcomes based on the actual and from the model estimated data as shown below. 
Table 3.4. The summary statistics of the variables in the model

\begin{tabular}{|l|l|l|c|c|} 
Outcomes involved in the model & \multicolumn{2}{|l|}{ From actual data } & $\begin{array}{c}\text { From model } \\
\text { estimation }\end{array}$ & \\
\cline { 2 - 5 } & Freq. & Percent & Means & Std. Dev. \\
\hline Non defaulter (0) & 49 & 30.25 & .3018383 & .3922969 \\
\hline Risky (1) & 58 & 35.80 & .3574134 & .3236383 \\
\hline Total & 55 & 33.95 & .3407483 & .3925115 \\
\hline
\end{tabular}

\section{Source: Computation result from field survey, 2017}

As revealed in the table 4.15 above, the loan repayment status of group leader respondents from the actual data explained that $35.80 \%$ of the MSE's sectors group leader respondents were from risky group borrower category and followed by defaulter and non defaulter group category accounting $33.95 \%$ and $30.25 \%$ respectively. Furthermore, based on the model estimation data that was analyzed from each individual observation in the data by using the predicted probabilities across each outcome from the ordered logistic model which means that the values of the means and percentage change across the three outcomes become closer and closer to each other indicating that we have a good individual prediction at average in the model.

This, applies to the data that meets the proportional odds assumption, which states that the ordinal logistic regressing model assumes that the coefficients that describe the relationship of the first value category versus all the second value category or the relationship of first poled categories versus all the second pooled categories were the same across all the category and interpreted based only on the sign of the independent variables (Peterson $\&$ Harrell, 1990).As a result, it was analyzed by using STATA software version 12 and the ordered logit regression results were interpreted as follows;

Table 3.5 Ordered logistic regression model result

$\begin{array}{lrl}\text { Ordered logistic regression model } & \text { Number of obs } & =162 \\ & \text { LR chi }^{2}(28) & =221.41 \\ \text { Log likelihood }=-66.875884 & \text { Prob }^{\circ} \text { chi }^{2} & =0.0000 \\ & \text { Pseudo } R^{2} & =0.6234\end{array}$

\begin{tabular}{|c|c|c|c|c|c|c|c|c|}
\hline \multirow{3}{*}{ Loan status } & \multicolumn{4}{|c|}{ Ordered logistic model output } & \multicolumn{4}{|c|}{ Result of marginal effects } \\
\hline & \multirow[t]{2}{*}{ Coef. } & \multirow{2}{*}{$\begin{array}{l}\text { Std. } \\
\text { Err. }\end{array}$} & \multirow[t]{2}{*}{$z$} & \multirow[t]{2}{*}{ P>I } & \multicolumn{2}{|c|}{ Probability to be non defaulter $\quad(y=0)$} & \multicolumn{2}{|c|}{$\begin{array}{l}\text { Propabilitityto, be defaulter } \\
(\mathrm{v}=2)\end{array}$} \\
\hline & & & & & $\mathrm{dx} / \mathrm{dx}$ & Std.Err. & $d x / d x$ & Std. Err. \\
\hline \multicolumn{9}{|c|}{ Demographic characteristics of respondents } \\
\hline GNDR $^{2}$ & -.0053 & 5413 & -0.01 & 0.992 & .0002 & .0271 & -0004 & 0409 \\
\hline AGE & 2841 & 4057 & 0.70 & 0.484 & -0142 & 0208 & .0214 & .0309 \\
\hline MRSTS & -0407 & 3165 & -0.13 & 0.897 & .0020 & .0158 & -.0030 & .0238 \\
\hline MSESE & 2689 & .1889 & 1.42 & 0.155 & -0134 & 0106 & .0203 & .0154 \\
\hline \multicolumn{9}{|c|}{ Group or the enterprises related factors } \\
\hline GLEL & -5109 & 2400 & -2.13 & $0.033^{* *}$ & .0256 & .0148 & -0386 & .0221 \\
\hline GLEX $^{2}$ & -1.932 & 6535 & -296 & $0.003^{*}$ & .1210 & .0625 & -1409 & 0589 \\
\hline EGS & 5576 & 1918 & 291 & $0.004^{*}$ & -0279 & .0136 & 0421 & 0171 \\
\hline GSS $^{2}$ & -8334 & .6398 & $-1,30$ & 0.193 & .0432 & .0365 & -0631 & 0534 \\
\hline ADNL $^{2}$ & 1950 & .6812 & 2.86 & $0.004^{*}$ & -0948 & .0449 & .1797 & .0854 \\
\hline LWNG $^{2}$ & -1685 & 5337 & -0.32 & 0.752 & .0084 & 0267 & -0127 & .0407 \\
\hline PIDR $^{2}$ & 2.494 & .6069 & 4.11 & $0.000^{*}$ & -1490 & .0601 & 2105 & .0708 \\
\hline EBC & -0001 & .0000 & -2.43 & $0.015^{\star \star *}$ & $3.22 \mathrm{e}$ & .0000 & $-4.85 \mathrm{e}$ & .0000 \\
\hline ELS & .0000 & .0000 & 124 & 0.215 & $-8.77 \mathrm{e}$ & .0000 & $132 \mathrm{e}$ & .0000 \\
\hline EEC & -.0000 & $9.65 \mathrm{e}-$ & -1.22 & 0.224 & $590 \mathrm{e}$ & .0000 & $-8.88 \mathrm{e}$ & .0000 \\
\hline PFSREF ${ }^{2}$ & 1341 & 5859 & 2.29 & $0.022 * \star$ & -0708 & .0437 & .1054 & 0596 \\
\hline NEMP & -0347 & 2641 & -0.13 & 0.895 & .0017 & 0132 & -.0026 & .0199 \\
\hline \multicolumn{9}{|c|}{ Institutional or lender related factors } \\
\hline EATL $^{2}$ & -3010 & 5603 & -0.54 & 0.591 & .0155 & .0304 & -0222 & .0408 \\
\hline IRRO $^{2}$ & 3189 & .7683 & 0.42 & 0.678 & -0160 & .0402 & .0241 & .0594 \\
\hline FULO $^{2}$ & -3.145 & 9585 & -3.28 & $0.001^{*}$ & .1833 & 0850 & -3066 & 1386 \\
\hline TLO $^{2}$ & -1.484 & .7576 & -1.96 & $0.050 * \pi$ & .0773 & 0460 & -.1202 & .0722 \\
\hline LRPS $^{2}$ & $-1,346$ & 6468 & -2.08 & $0.037 * \pi$ & .0701 & .0428 & -1073 & 0609 \\
\hline LIR $^{2}$ & 2.401 & 6185 & 3.88 & $0.000^{*}$ & -1318 & .0514 & 2147 & 0731 \\
\hline \multicolumn{9}{|c|}{ Exterual or enviroument related factors } \\
\hline $\mathrm{PSH}^{2}$ & 2354 & 9851 & 0.24 & 0.811 & -0118 & .0499 & 0177 & 0747 \\
\hline PPI $^{2}$ & 2.135 & .7854 & 2.72 & $0.007^{*}$ & -1426 & .0782 & .1517 & .0662 \\
\hline SHWS $^{2}$ & 1529 & .7045 & 2.17 & $0.030 * \pi$ & -0846 & .0513 & .1179 & .0632 \\
\hline $\mathrm{ROA}^{2}$ & -6971 & 5894 & -1.18 & 0.237 & .0361 & .0358 & -0523 & .0472 \\
\hline LAIM $^{2}$ & 4348 & 9152 & 0.48 & 0.635 & -0220 & .0470 & .0328 & .0702 \\
\hline AOMFP' & -1.410 & 8292 & -1.70 & $0.089 * \star \star \pi$ & .0693 & .0497 & -1192 & .08405 \\
\hline /cutl & -6355 & 1946 & & & & & & \\
\hline /cut2 & 4658 & 2.038 & & & & & & \\
\hline
\end{tabular}

Source: Computation result from field survey, 2017.

$*, * * \& * * *$ indicates the level of significance at 1 percent, 5 percent and 10 percent respectively.

(a) $\mathrm{dy} / \mathrm{dx}$ is for discrete change of dummy variable from 0 to 1. As detailed in the 4.16above, at the top of the output we see that $\mathbf{1 6 2}$ 0bservations in this data set were used for analysis. The likelihood ratio Chi-square (28)of 221.41 with p- value of $\mathbf{0 . 0 0 0 0}$ tells us that this model composed of more suitable significant variables comparative 
to insignificant predictors and this indicates that whether the combined effect of all the variables in the model is different from zero or not. For example if "P>z" $<\mathbf{0 . 1}$ then the model have some relevant explanatory power, which does not mean that all variables are significant and does mean that the coefficients, standard errors, z- test and $95 \%$ of confidence interval, the data were well suited with the model.

In this study, the demographic characteristic of respondents does not have a significant effect on the group loan repayment performance of MSE's sectors in the study area. Lastly, the cut1 and cut2 at the bottom of the result are the two intercepts in the model indicating that the value of the dependent variable in the model has three outcomes in which the ordered logit model is preferred for the data analysis.

\subsubsection{Interpretations and discussions of the model result.}

\subsubsection{Interpretations of the coefficients in the model}

In this model we are not allowed to interpret the magnitude of the independent variables rather only the sign of the variables across the model was interpreted based on the classifications of the independent variable's related factors such as; the enterprises, institutional and the external related factors that influence the group loan repayment performance of MSE sectors financed by East Wollega Zone of OCSSCO focusing on the significant variables $(" \mathbf{P}>\mathbf{Z}$ " $<\mathbf{0 . 1})$ in the model.

Additionally, the corresponding marginal effects at two outcomes i.e. non defaulter and defaulter $(y=0$ and $y=2$ ) loan repayment status were interpreted. Here, the marginal effect focused on the two outcomes because of that at the risky loan status (outcome 2 or $\mathbf{y}=\mathbf{2}$ ) the marginal effect across the variables in the model were insignificant. These interpretations in the model were explained separately as follows.

\subsection{1.1. The effect of Group-Specific Factors that influence the loan repayment performance of MSE's} sectors.

In this case the effects of the variables listed under the group or enterprises related factors were interpreted based on the sign of each variable which states that; With the higher years of group leaders education level, the more likely to be in the lower category (non defaulter) of the group loan repayment status of the MSE sectors which means that the more qualified the group leader of MSE sectors, the more likely to pay their loan timely at the repayment schedule in the study area and statistically significant at 5\% level of significance. With the higher years of group leaders experience in the business, the more likely to be in the lower category (non defaulter) of the MSE sectors group loan repayment status which means that the higher years of group leaders experience in the business, the more likely to pay their loan timely at the repayment schedule in the study area and statistically significant at $1 \%$ level of significance.

With the higher in group size of the MSE sectors the more likely to be in the higher category (defaulter) of the group loan repayment performance which means that the higher the group size of the MSE sectors the less likely to pay their loan timely at the repayment schedule in the study area and statistically significant at $1 \%$ level of significance. With the higher additional loan received by the MSE sectors the more likely to be in the higher category (defaulter) of the group loan repayment performance which means that by receiving the additional loan the more likely that they defaulted and statistically significant at $1 \%$ level of significance. With the higher in the problem of information disclosure among members of the MSE sectors the more likely to be in the higher category of the group loan repayment performance this means that the more likely to be in the defaulter group category and statistically significant $1 \%$ level of significance.

With the higher the enterprise's beginning capital in the business start up, the more likely to be in the lower category (non defaulter) of the group loan repayment performance by the MSE sectors which means that the higher the enterprise's beginning capital in the business start up, the more likely to pay their loan timely at the repayment due date and statistically significant at $5 \%$ level of significance.

With the higher in the problem of financial statement recording experience of the MSE sectors the more likely to be in the higher category (defaulter) of the group loan repayment performance which means that having the problem of financial statement recording experience they couldn't be able to pay their loan on the repayment schedule and statistically significant at $1 \%$ level of significance. Because, they couldn't be properly managed the expense and revenue related activities of their business.

\subsection{The effect of Institutional or lender specific factors that determine the group loan repayment performance of MSE's Sectors}

The effect of the variables under the Institutional or lender specific factors was interpreted based on the sign of each variable as before which states that; With the higher follow up activities by the loan officer of OCSSCO in the business, the more likely to be in the lower category (non defaulter) of the group loan repayment performance of the MSE sectors which means that the higher follow up activities by the loan officer increases the probability that the MSE sectors to pay their loan timely versus risky and defaulter groups and statistically significant at $1 \%$ level of significance.

With the higher training activities by the loan officer of OCSSCO in the business, the more likely to be in the lower category (non defaulter) of the group loan repayment performance of the MSE sectors which means that the higher training activities offered by the loan officer increases the probability that the MSE sectors to pay their loan 
timely and statistically significant at $5 \%$ level of significance.

With the higher the suitability of the loan repayment period, the more likely to be in the lower category of the group loan repayment performance or status of the MSE sectors which means that the more likely to be in the non-defaulter group category and statistically significant at 5\% level of significance.

With a one unit increase in the loan interest rate offered by the OCSSCO, the more likely to be in the higher category (defaulter) group that MSE sector's group loan repayment performance belongs to, which means that with the higher loan interest rate, the MSE sectors fails to pay their loan at its repayment schedule which enhanced them to be defaulter group category versus risky and non defaulter groups and statistically significant at $1 \%$ level of significance

\subsection{The effect of external related factors that influence the group loan repayment performance of MSE's sectors}

The effect of the variables under the external related factors was interpreted based on the sign of each variable which says that; With the higher the problem of power interruption that the MSE sectors faced, the more likely to be in the higher category (defaulter) of the group loan repayment performance which means that higher the problem of power interruption, the more probably that MSE sectors couldn't perform well in paying their loan timely and statistically significant at $1 \%$ level of significance.

An increase in the shortage of water supply that the MSE sectors faced, the more likely to be in the higher category of the group loan repayment status which means that as the problem of water supply increases the more likely that MSE sectors become defaulted and statistically significant at 5\% level of significance.

With the higher the accessibility of output market for the MSE's finished product, that the group loan repayment status of the MSE sectors become more likely to be in the lower category or non defaulter which means that as they are accessed to output market the more likely that the MSE sectors pay their loan properly versus risky and defaulter groups and it is statistically significant at $10 \%$ level of significance.

\subsubsection{The interpretations relating to marginal effects in the model.}

An interpretation of the marginal effect tells us that by how many percent that the probability of the group owned of MSE's sectors loan repayment performance to be non defaulter, risky or defaulter groups if the explanatory variables changes by one unit at the three successive outcomes separately. The rule of marginal effect in ordered logit model states that if we have more likely in one category we have less likely in another category by focusing on the significant variables in the model. In this study, since the marginal effects in the ordered logit model for the second outcome at $Y=1$ couldn't be incorporated in this interpretation because of that the marginal effect of the large independent variables in the model output become insignificant and this is one of the drawback of ordered logit model(Pindyck\&Rubinfeld, 1998).

As a result, the interpretations of the marginal effect at the first $(\mathrm{Y}=0)$ and the second outcome $\mathrm{Y}=2)$ were well discussed by focusing only on the significant variables in the model by rejecting the null hypothesis of the insignificant variables, because of that their difference in describing power among those variables that they have on the loan repayment performance of MSE sectors in the study area which is interpreted as follows:A one-unit increase in the group leader's education level leads to increase the group loan repayment performance of MSE sectors to be non- defaulter by $2 \%$ and decreases the probability to be defaulter by $4 \%$ holding the other variables in the model constant or ceteris Paribus. A one unit increase in the group leader's experience in the business, leads to increase the group loan repayment performance of MSE sectors to be non defaulterby $12 \%$ and decreasing the probability to be defaulter by $14 \%$ holding the other variables in the model constant or ceteris Paribus.

Adding a one individual to the enterprises group size in the business, it leads to decrease the group loan repayment performance of MSE sectors to be non defaulter by $3 \%$ and increases the probability to be defaulter by $4 \%$ and ceteris paribus. A one unit increase in the additional loan to their business, it leads to decrease the group loan repayment performance of MSE sectors to be non defaulter by $9 \%$ and increases the probability to be defaulter by $17 \%$ ceteris paribus. With the per unit increase in the problem of information disclosure among the members, leads to decrease the group loan repayment performance of MSE sectors to be non defaulter by $14 \%$ and increases the probability to be defaulter by $21 \%$ ceteris paribus. A one unit increase in the problem of financial statement recording experience in the business, it leads to decrease the group loan repayment performance of MSE sectors to be non defaulter by $7 \%$ and increases the probability to be defaulter by $10 \%$ ceteris paribus.A onetime increase in the follow up by the loan officers of OCSSCO, it leads to increase the group loan repayment performance of MSE sectors to be non defaulter by $18 \%$ and decreasing the probability to be defaulter by $30 \%$ ceteris paribus.

A one unit increase in the training offered by the loan officers of OCSSCO; it leads to increase the group loan repayment performance of MSE sectors to be non defaulter by $8 \%$ and decreasing the probability to be defaulter by $12 \%$ ceteris paribus.A onetime increase in the suitability of the loan repayment period, it leads to increase the group loan repayment performance of MSE sectors to be non defaulter by $7 \%$ and decreases the probability to be defaulter by $10 \%$ ceteris paribus.A one unit increase in the loan interest rate levied by OCSSCO, it leads to decrease the group loan repayment performance of MSE sectors to be non defaulter by $13 \%$ and increases the probability to be defaulter by $2 \%$ ceteris paribus. A one unit increase in the problem of power interruption around the enterprise 
working area, it leads to decrease the group loan repayment performance of MSE sectors to be non defaulter by $14 \%$ and increases the probability to be defaulter by $15 \%$ ceteris paribus.

A one unit increase in the shortage of water supply around the enterprise working area, it leads to decrease the group loan repayment performance of MSE sectors to be non defaulter by $8 \%$ and increases the probability to be defaulter by $11 \%$ ceteris paribus.A one unit increase in the access to output market for the enterprise's finished product around their working area, it leads to increase the group loan repayment performance of MSE sectors to be non defaulter by $6 \%$ and decreases the probability to be defaulter by $11 \%$ ceteris paribus.

\section{Summary, Conclusions and Recommendations}

\subsection{Summary}

Micro Finances are financial institutions that are supplying loans and small credits to finance small business entities to help the poor and unemployed individuals through forming them in group owned of micro and smallscale enterprises (MSE's) which enables them to earn their daily income and to be able to better their living standard. These MSE's are financed by East Wollega Zone of OCSSCO and this study was concerned with the factors that influence the group loan repayment performance of micro and small-scale enterprises by categorizing these factors as the enterprises, institutional and the external related factors in the study area for analyzing purpose. Furthermore, this study were employed both descriptive and ordered logit model in order to analyze the data collected through structured questionnaire in which 6 respondents were couldn't filled the questionnaire and only 162 of the filled properly out of 168 determined sample size from 424 total group owned of MSEs included in the study. Thus, the result of this study indicates that the group loan repayment performance of MSE sectors were affected by various factors like; the enterprises group size, the additional loan they granted from OCCSCO, the problem of information disclosure among members especially about their loan repayment status, The problem of financial statement recording experience in the business, the loan interest rate offered by the OCCSCO, the problem of power interruption in their enterprise's business working area and shortage of water supply influences them either to fall in non defaulter, risky or defaulter status category in the study area.

\subsection{Conclusions}

This study were employed both the descriptive and ordered logit model in order to identify the factors that determine group loan repayment performance of MSE sectors by categorizing them as the enterprises, institutional and the external related factors Thus, the author identified that the group loan repayment performance of MSE sectors were influenced both positively and negatively by the group or enterprise related factor like group leaders education level, group leaders experience in another similar business positively while the large group size, problem of information disclosure, problem of financial statement recording experience, the additional loan they granted from OCSSCO were influenced negatively, the institutional related factor like; loan interest rate negatively influences while training and follow-up were positively affecting and among the external related factor like; problem of power interruption and shortage of water supply negatively affects whereas access to output market for the enterprises finished products are those factors that influence the enterprises group loan repay

\subsection{Recommendations}

In this finding, depending up on the above analyzed data and conclusions drawn, the following recommendations were forwarded based on the ordered logit model result, about the determinant of the group loan repayment performance of MSE sectors that were classified as group related, institutional and external related factors that are financed by East Wollega Zone of Oromia Credit and Saving Share Company as follows. Firstly, the loan officers of OCCSCO has to provide a frequent training activities and follow up to the borrowers of MSE sectors and they aware out their financial management activities like saving habit the financial statement recording experience that enables them to manage the expense and revenue related activities of their business in the study area.

Furthermore, the problem of information disclosure among the members should be resolved by the financing agency through preparing apanel discussion on timely bases with all the group members in the MSE sectors rather than only discussing with the group leaders in order to inform that the either the category of their loan repayment status was non defaulted, risky or defaulted.

In similar way, the higher a number of members or group size of the MSE sectors results in the conflict of interest that leads to create disagreement among members which in turn affects their loan repayment activities to avoid this OCSSCO should aware the enterprises that the lower group size performs well in paying their loan than the larger group size in the study area as well as the loan interest rate has to be in a way that it is affordable by the borrowers.

Its better if OCSSCO not disburse additional loan simply without deep scanning about the enterprise's financial strength because, it results in the credit over burden and become beyond their capacity to pay back. Another thing to be considered during the time of loan approval and disbursement by the loan officers of OCSSCO includes the group leaders of MSE sectors should be academically matured and the experienced group leader in 
another similar business were highly recommended in this study area.Lastly, the MSE enterprises beginning capital at their business startup, contributes to the better loan repayment performance as a result, OCSSCO should create awareness to the borrowers in order as much as possible in order to contribute more which helps them in building confidence to the groups in paying their loan on the scheduled due date. Lastly, since the group loan repayment performance of the MSE sectors were also affected by the external related factors like; shortage of water supply and problem of power interruption around the enterprise's business working area, both the loan officers and managers of OCSSCO has to deal with the concerned body in order to facilitate the smooth functioning of the enterprise's business with their respective sectors in the study area.

\section{References}

Abafita, J (2013). Microfinance and Loan Repayment Performance: A Case of the Oromia

Credit and Savings Share Company (OCSSCO) inKuyu.Thesis paper at Addis Ababa University.

AbebeBayuCheriye (2013), Microfinance and Loan Repayment Performance, CaseOromia Credit and Savings Share Company (OCSSC), Ethiopian, Zenith InternationalJournal of Multi Disciplinary Research, Vol.3, January, 2013.

Abraham, G. (2002). Loan repayment and its determinants in small scale enterprisesfinancing in Ethiopia: A case of private borrowers around Zeway Area (Master Thesis).Addis Ababa University.

Acquah, H. D., Addo, J. (2011) Determinants of Loan Repayment Performance of Fishermen: Empirical Evidence from Ghana. Moldova, 2011, Vol. XLIV, No. 4 (148).

Agresti, A. (2007). An Introduction to Categorical Data Analysis. John Wiley and Sons, Inc, New York.

Bassem, S. (2008). Determinants of successful group loan repayment: An application to Tunisia. Journal of Sustainable Development in Africa, 10 (2), 776-792.

Canadian International Development Agency (CIDA, 2007) Supporting the Development of Inclusive Financial Systems: Micro Finance Guidelines.

Chattereje, S., Hadi, A., \& Price, B. (2000).Regression analysis by example (3rd ed.). New York: John Wiley and Sons.

Cheng T. C. E. and. Choy Petrus W.C (2007), Measuring Success Factors of QualityManagement in the Shipping Industry.

ChristenR. P, Lyman T.R. and Rosenberg R. (2003) Guiding Principles on Regulation Supervision of Microfinance: Published In The United States of America, Washington, D.C.

East Wollega Zone Oromia Credit and Saving Share Company.(2016).Annuafinancial statement report.

East Wollega Zone Finance and Economic Development Office, 2017.

Eze C.C. and Ibekwe U.C. (2007) "Determinants of loan repayment under the indigenous financial systems in Southeast" Nigeria' Journal of social science 2(2) $116-120$.

Fikirte K. R (2011) "Determinants of loan repayment performance: A case study in the Addis Credit and Saving Institution." Addis Ababa, Ethiopia. Wegeningen

University, Netherlands.

Francis. O \& Abel.K, (2009). Determinants of loan repayment performance in microcreditinstitutions:Evidence from Tanzania (Master Thesis). University of Dar Es Salaam, Tanzania.

Gujarati, D. (2004). Basic Econometrics (4th Ed.). New York, NY: McGraw-Hill companies.

Hosmer, D., \&Lemeshow, S. (1980). A goodness of fit test for the multiple logisticregression model. Communications in Statistics Journal, 10 (1), 1043-1069.

JemalAbafita (2003), "Microfinance and Loan Repayment Performance: A Case Study of theOromia Credit and savings Share Company in Kuyu," Msc. Thesis, AAU.

Joanna Ledger wood (2013) A Financial Market System Perspective: The New MicrofinanceHandbook, Washington, DC: World Bank.

Mcfadden, D. (1973) the measurement of urban travel demand, Journal of public economics.

MeleseKebede, TesfahunTegegn, and TadeseTafese (2014). Factors Affecting LoanRepayment Performance of Small Scale Enterprises Financed by MicroFinance Institutions: Study on Private Borrowers around Wolaita and Dawuro Zone. Global Journals Inc. (USA), Volume 16 Issue 7 Version 1.0 Year 2014.

Meshesha, T. (2014). Microfinance Credit Rationing and Loan Repayment Performance.MSc. Thesis Addis AbebaUniversity..

Munene, H and Guyo, S. (2013). Factors Influencing Loan Repayment Default in Micro-Finance Institutions.Thesis atMeru University of Science and Technology Kenya.

Michael S. Barr (2004) Microfinance and Financial DevelopmentMichiganJournal of International Law, Vol.26 No. No. 1, Pp. 271-96.

Micro Finance Development Review (2000), Vol. 1, No.1, Addis Ababa MFDR Vol.2, No. 1, Addis Ababa.Ethiopia.

Mohamed Jamal, (2013) Annual conference on the Ethiopian economic development association. 
Mohana R.K. andLoddego T.F (2013). Credit provision and savingmobilization ofmicro finance institutions in Ethiopia. International Journal ofaccounting and financial management research vol.3.

Million Sileshi, Rose Nyikal and Sabina Wangia (2012), Factors Affecting Loan Repayment performance of Smallholder Farmers in East Hararghe, Ethiopia, Developing Country Studies, Vol.2, No.11, 2012.

Nawai, N. and Shariff, M. N. M. (2013) "Loan Repayment Problems in Microfinance Programs that uses Individual Lending Approach: A Qualitative Analysis. Journal of Transformative Entrepreneurship Vol. 1, Issue 2, pp.93-99.

Ngai, E.W.T., Cheng, T.C.E. and Ho, S.S.M. (2004). Critical success factors of web based Supply-chain management systems: an exploratory study. Production Planning \& Control, 15(6), 622-630.

NorhaziahNawai and Mohd Noor MohdShariff. (2010) Determinate of Repayment Performance in Micro Credit Programs: International Journal of Business and Social Science Vol.1 No.2,November, 2010.

Okibo W .B.andAseyo L. (2013). Causes of loan default within micro financing Institutions in Kenya.Interdisciplinary journal of contemporary research in business vol.4.

Peterson, B. \& Harrell, F. E. (1990).Proportional odds assumption of models for ordinal response variables.Applied Statistics, 39(3), 205-217.

Pindyck R.S. and Rubinfeld D.L. (1998) 'Econometric models and Economic forecasts,fourth edition, the McGraw-Hill companies, United Stated of America.

Ralph, H. (2011). Background information on group lending. Nairobi, Kenya

Robinson,M. (2003). The microfinance revolution: Sustainable finance for the Poor. Washington, D.C: World Bank.

Rose A.B. Wakuloba(2007). Ministry of State for Youth Affairs, Kenya.

ShaikA.andTolosa N. (2014).Performance of Loan Repayment Determinants in Ethiopian Micro Finance Analysis.Eurasian Journal of Business and Economics 2014,29-49.

ShaikAbdulahi (2014)Microfinance credit and Loan Repayment Performance: Case of Sidama Micro Finance Institution.

Sileshi M., Nyikal R. and Wangia S. (2012) "Factors Affecting Loan Repayment Performance of smallholder Farmers in East Hararghe, Ethiopia.” Developing Country Studies, Vol 2, No.11.Signoriello, V. J. (1991). Commercial Loan Practices and Operations, Bankers Publishing.

Stock, J., \& Watson, M. (2007).Introduction to econometrics.(2nd ed.). Botson: Pearson Addison Wesley.

SolomonAlemu andAddisuBajira (2013), Determinants of Rural HouseholdsLoan RepaymentPerformance, In Oromia National Regional State: The Case of DodotaWoreda: InternationalJournal of Research In Computer Application \& Management, Vol.3, No.11, November, 2013.

Dr. TesfatsionSahlu,GedifewAgalu and WelderufaelLeake. (2015). Factors Influencing MFIs Group Loan Repayment Performance of MSEs.Research Journal of Finance and Accounting.

TesfayeGinbare,TesfatsionHailu andKirosHabtu. (2014). Determinants of grouploan repayment performance of MSEs.Research Journal of Finance and Accounting, 11.

Train, K. E. (2009). Discrete Choice Methods with Simulation (Second edition). Cambridge and New York,Cambridge University Press.

TriodosFacet (2013),Policy Review and Private Sectors Development: Country Report of Ethiopia,January 2013, Netherlands.

Una Murray and RuxandraBoros (2002) A Guide to Gender Sensitive Microfinance, Socio-Economicand Gender Analysis Programme (Seaga), Fao

Verbeek, M. 2008. A guide to modern econometrics, Wiley Vijverberg, W. 2011.Testing for IIA with the Hausman-McFadden test.

Watson, Jeff (2001). How to determine a sample size: tipsheet \#60, University Park, PA:Penn State Cooperative Extension.

Windmeijera F.A.G. (1995) 'Goodness-of-fit measures in binary choice models, Econometric Reviews, 14(1), 101116, Department of Statistics Faculty of Economics and Commerce, The Australian National University, Canberra, ACT, Australia.

Wolday A.and GebreHiwot A. (2002).Micro and Small Enterprise Finance in Ethiopia.Eastern Africa Social Science Research Review.Vol.22.No.1.

WoldayAmha (2008), Review of Microfinance Industry in Ethiopia: Regulatory Framework andPerformance, Occasional Paper No. 2

Wongnaa C. A. and Awunyo-Vitor D. (2013) "Factors affecting loan repayment Performance among Yam farmers in the Senedistrict, Ghana." Agris on-linePapers in Economics and Informatics Vol. No. 2.

Zeller, M. (1998). Determinants of loan repayment performance in credit groups: the role of program design, intra group risk pooling, and social cohesion.Journal ofEconomic Development and Cultural Change, 46(3), 599-620.

Zerai B. and Rani L.(2012). Technical efficiency and its determinants of microfinance institutions in Ethiopia.stochastic frontier approach, African journal of Accounting. 